\title{
Economical method for midiprep plasmid DNA purification using diatomaceous earth
}

\author{
Decha Sermwittayawong*, Chanawee Jakkawanpitak, Nureeya Waji, Nongporn Hutadilok-Towatana \\ Department of Biochemistry, Faculty of Science, Prince of Songkla University, Hat Yai 90110 Thailand \\ *Corresponding author, e-mail: decha.s@psu.ac.th \\ Received 27 Feb 2013 \\ Accepted 2 Sep 2013
}

\begin{abstract}
Diatomaceous earth has been used for DNA purification as it can produce high quality plasmid DNA. We describe an alternative and economical method for plasmid DNA purification from a 50-ml bacterial culture using diatomaceous earth, plastic pipette tips, conical tubes, centrifuges, and without requiring a vacuum system. Depending on the plasmid size and the origin of replication, this method yielded $200-800 \mu \mathrm{g}$ plasmids with an $\mathrm{A}_{260} / \mathrm{A}_{280}$ of 1.8-2.0. These purified plasmids are suitable for many applications such as DNA sequencing and transfection experiments.
\end{abstract}

KEYWORDS: spun column, centrifugation, $\mathrm{A}_{260} / \mathrm{A}_{280}$

\section{INTRODUCTION}

Diatomaceous earth (DE) is among the best reagents for plasmid DNA purification because it can produce a high quality plasmid DNA. Several methods using DE for DNA purification have been described. In principle, DNA binds to silica dioxide, which is the major component of diatomaceous earth, in the presence of chaotropic salts such as guanidine hydrochloride, NaI, and guanidine isothiocyanate ${ }^{1}$. The chaotropic agent denatures proteins and is subsequently washed away. Resin-bound DNA is collected in a plastic column using a vacuum manifold. After subsequent washes, bound DNA could be recovered using hot water (e.g., $70-80^{\circ} \mathrm{C}$ ).

In order to obtain a high quality and sufficient amount of plasmid DNA for transfection assay, at least a midiprep scale of purification (i.e., $50-\mathrm{ml}$ bacterial culture) is required. However, purification procedures of plasmid DNA in a medium and large scales require a vacuum system and/or commercial spun columns, which might not be available in some laboratories. In addition, commercially available kits for plasmid DNA purification are relatively expensive. A lowcost method that confers a high quality plasmid DNA is preferred in many laboratories. In this work, we developed an economical method for plasmid DNA purification using DE, without the need for a vacuum system and commercial spun columns. Tubes (15$\mathrm{ml}$ conical tubes), tips (5-ml plastic pipette tips), a high-speed centrifuge and a swing-out centrifuge are the major pieces of equipment used in this protocol. With our method, we were able to obtain 200-800 $\mu \mathrm{g}$ plasmids from a 50-ml bacterial culture. The purified plasmids are in a high quality, with the $\mathrm{A}_{260} / \mathrm{A}_{280}$ ratios between 1.8 and 2.0 and they can be used directly for many applications, including DNA sequencing and transfection into tissue culture cells.

\section{MATERIALS AND METHODS}

\section{Cell culture}

A single colony of Escherichia coli DH5 $\alpha$ strain harbouring a desired plasmid DNA was inoculated in a 500-ml Erlenmeyer flask containing $50 \mathrm{ml} 2 \times \mathrm{TY}$ medium supplemented with $100 \mathrm{mg} / \mathrm{ml}$ ampicillin. The flask was placed in an orbital shaker and incubated at $37^{\circ} \mathrm{C}, 220 \mathrm{rpm}$ for $16-18 \mathrm{~h}$. After centrifugation, cell pellet was kept at $-20^{\circ} \mathrm{C}$ until the plasmid purification was performed.

\section{Alkaline lysis \\ The alkaline lysis method was modified from a pre- vious protocol by Dr Ravi Iyer ${ }^{2}$. Briefly, cell pellet was resuspended with $5 \mathrm{ml}$ solution $1(25 \mathrm{mM}$ Tris-Cl pH 8.0, $50 \mathrm{mM}$ glucose, $10 \mathrm{mM}$ EDTA, and $40 \mu \mathrm{g} / \mathrm{ml}$ Rnase A), and transferred into a clean 50-ml conical tube. To lyse the cells, $10 \mathrm{ml}$ solution $2(0.2 \mathrm{M}$ $\mathrm{NaOH}$ and $1 \%$ SDS) was added. The sample was gently mixed by inversion 2-3 times, and incubated at room temperature for $5 \mathrm{~min}$. Following the incuba- tion, $5 \mathrm{ml}$ solution $3(1.25 \mathrm{M}$ potassium acetate and 1.25 $\mathrm{M}$ acetic acid) was subsequently added and the sample was inverted for a few times. Immediately after inversions, the tube was incubated on ice for $30 \mathrm{~min}$. An addition of solution 3 caused a formation}




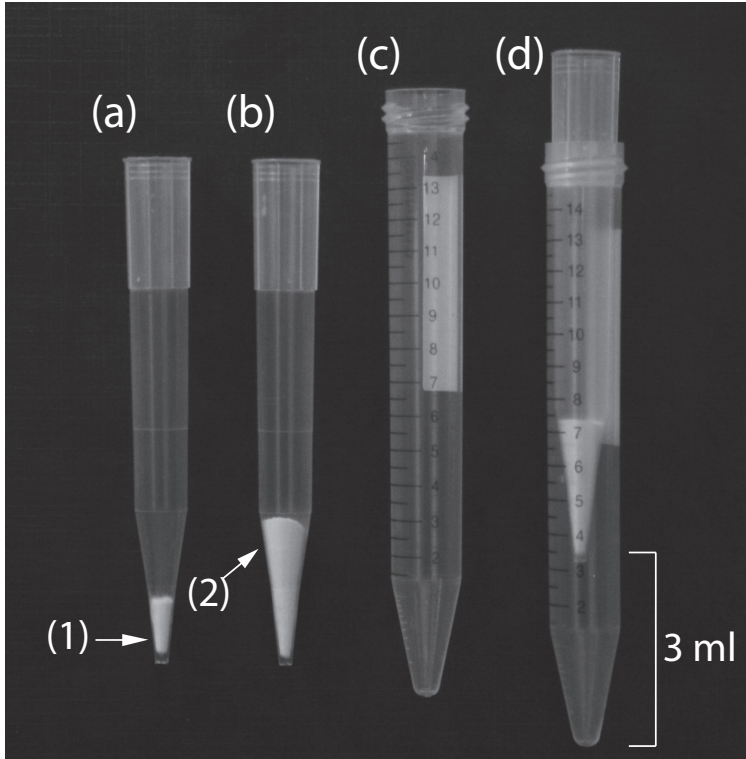

Fig. 1 Home-made spun column. (a) A 5-ml plastic pipette tip stuffed with some cotton (1); (b) A stuffed tip filled with diatomaceous earth or DE (2); (c) a 15-ml conical tube; (d) a home-made spun column made from a stuffed tip (b) and a tube (c). Notice that after fitting the tip, there is a 3-ml dead space volume, which serves as a reservoir for liquid collection.

of white fluffy precipitates, which were subsequently removed by filtration through a Whatman paper. The clear supernatant was transferred to a $35-\mathrm{ml}$ screwcapped tube, followed by an addition of 0.6 volume isopropanol. After vigorous shakings, the sample was placed on ice for 5-10 min and subsequently centrifuged at $12000 \mathrm{~g}$ for $10 \mathrm{~min}$ to precipitate the DNA. After removing the supernatant, a DNA pellet was showed that could be stored at $-20^{\circ} \mathrm{C}$ or be taken to the next step.

\section{Home-made column}

A spun column for plasmid DNA isolation was made of a 5-ml plastic pipette tip (for a P-5000 pipette), a 15-ml tube (Corning), and cotton. First, the narrow end of a plastic pipette tip was stuffed tightly with some cotton, which retains the resin during centrifugation (Fig. 1a and b). Then, a spun column was created by inserting a stuffed tip in a $15-\mathrm{ml}$ conical tube (Fig. 1d).

\section{Purification with diatomaceous earth (DE)}

Purification procedures and the binding buffer were modified from the previous protocol ${ }^{3}$. First, the isopropanol-precipitated pellet was resuspended with
$1000 \mu \mathrm{l}$ Milli-Q water, followed by an addition of 5$10 \mathrm{ml}$ binding buffer (7 M guanidine hydrochloride $(\mathrm{GuHCl})$ in $50 \mathrm{mM}$ Tris-Cl buffer $\mathrm{pH} 7.0$, and $20 \mathrm{mM}$ EDTA). Then, $1.0 \mathrm{~g}$ diatomaceous earth (Sigma D5509) was added, and the sample was rocked at a slow speed at room temperature for 45-60 min. During the incubation, the tube was inverted for a few times every 15-20 min to ensure a maximum binding of DNA to the resin. After incubation, the sample was mixed by inversion and equally split into 4 homemade spun columns. Using a swing-out centrifuge, the resins were sedimented at a speed of $2900 \mathrm{~g}$ for 5 min and the flow-through was transferred to a clean tube for troubleshooting. The resin in each column was washed twice with $3 \mathrm{ml}$ solution $4(20 \mathrm{mM}$ Tris-Cl pH 7.5, $200 \mathrm{mM} \mathrm{NaCl}, 5 \mathrm{mM}$ EDTA, and $50 \%$ ethanol). Subsequently, the spun columns were centrifuged for another $10 \mathrm{~min}$ to dry out the resin. Prior to eluting the DNA, each tip with dried DE was transferred to a dry and clean conical tube, which would be used for collecting the DNA. The elution was performed twice by adding $250 \mu \mathrm{l} 72{ }^{\circ} \mathrm{C}$ Milli-Q water to the resin and immediately centrifuged at the same speed for $5 \mathrm{~min}$. The first and second eluates could be combined and used directly for many analyses such as gel electrophoresis, restriction digestion, sequencing, and transfection assay. The $\mathrm{A}_{260}$ and $\mathrm{A}_{280}$ absorbances of the plasmids were determined using HP8453 UV-Vis Spectrophotometer.

\section{Transfection experiment}

The pCI-HAhIRF3 plasmid purified with this method was transfected into HEK293T cells (ATCC: CRL11268) with Trans LT1 (Mirus), using the protocol described by the manufacturer's instruction. Cells were harvested $48 \mathrm{~h}$ post-transfection and stored at $-80{ }^{\circ} \mathrm{C}$ until needed.

\section{Cell lysis}

Frozen cell pellets were lysed on ice for $30 \mathrm{~min}$ with lysate buffer (50 mM Tris-Cl pH 7.4, $150 \mathrm{mM}$ $\mathrm{NaCl}, 1 \mathrm{mM}$ EDTA, $0.5 \% \mathrm{NP}-40,1 \times$ complete set protease inhibitors from Roche, $1 \mathrm{mM} \mathrm{NaF}$, and $1 \mathrm{mM}$ $\mathrm{Na}_{3} \mathrm{VO}_{4}$ ). Cellular debris was removed by centrifugation. Soluble extracts were resolved by SDS-PAGE and transferred to a nitrocellulose membrane (BioRAD).

\section{Western blot analysis}

Western blotting was used to analyse the expression of HA-tagged hIRF3, using anti-HA tag (ABCAM). All steps were performed at room temperature unless indicated. Proteins on the membrane can be visualized 
by staining with $0.2 \%$ Ponceau Red in $10 \%$ acetic acid and destained with distilled water. Subsequently, the membrane was blocked with blocking solution (5\% non-fat milk in $1 \times$ TBST, which contains $0.025 \mathrm{M}$ Tris- $\mathrm{Cl} \mathrm{pH} \mathrm{8.0,} 150 \mathrm{mM} \mathrm{NaCl}$, and $0.05 \%$ Tween 20) for $1 \mathrm{~h}$ with constant rocking. The membrane was washed $3 \times 5$ min with $1 \times$ TBST and incubated with $10 \mathrm{ml}$ 1:4000 diluted anti-HA tag monoclonal antibody (ABCAM) for $2 \mathrm{~h}$ using the same incubation condition. The membrane was then washed with $1 \times$ TBST for 3 times, 5 min interval before subjected to a 2-h incubation with an anti-rabbit HRP conjugated secondary antibodies (GE Healthcare) diluted 1:10000 with $1 \times$ TBST. Subsequently, the membrane was washed $3 \times 5$ min with $1 \times$ TBST before adding SuperSignal West Pico Chemiluminescent Substrate (Pierce) and exposed to an X-ray films (Pierce) at various time. X-ray film was developed with an X-ray film-processing machine.

\section{RESULTS AND DISCUSSION}

In the present study, we proposed an alternative technique for plasmid DNA purification in a midi-scale and optimized the protocol for a maximum plasmid yield. Our home-made spun column is made of a cotton-stuffed plastic pipette tip and a $15-\mathrm{ml}$ conical tube (Fig. 1). With a type of 5-ml plastic tip we used, we found that it fitted well with a $15-\mathrm{ml}$ conical tube from Corning. Any brand of 15-ml tube could probably be used, as long as the stuffed tip can be removed from the tube after centrifugation. In addition, the $3 \mathrm{ml}$ dead volume in the column is required because it is used as a reservoir for liquid resulted from centrifugation (Fig. 1d). We found that $1.0 \mathrm{~g}$ of DE would give the highest yield of plasmid (data not shown). With the amount of resin and buffer used, 4 home-made columns are required for one 50$\mathrm{ml}$ bacterial culture.

Because plasmid purification with DE described in literature used hot water or Tris-EDTA buffer pH 8.0 to elute the DNA from the resin, we wondered whether these two solutions could efficiently elute the DNA. Thus we compared the efficiency of 4 elution solutions: hot Milli-Q water at $72^{\circ} \mathrm{C}$, room temperature Milli-Q water, ice-cold Milli-Q water, and $10 \mathrm{mM}$ Tris- $\mathrm{Cl} \mathrm{pH}$ 8.0. We found that hot Milli-Q water was the best elution solution, although the yield does not appear to be different from that using water at room temperature (Fig. 2). Interestingly, $10 \mathrm{mM}$ Tris$\mathrm{Cl} \mathrm{pH} 8.0$ was found to be the worst elution solution for this protocol.

In addition to analysing different elution solutions, we determined whether this protocol would

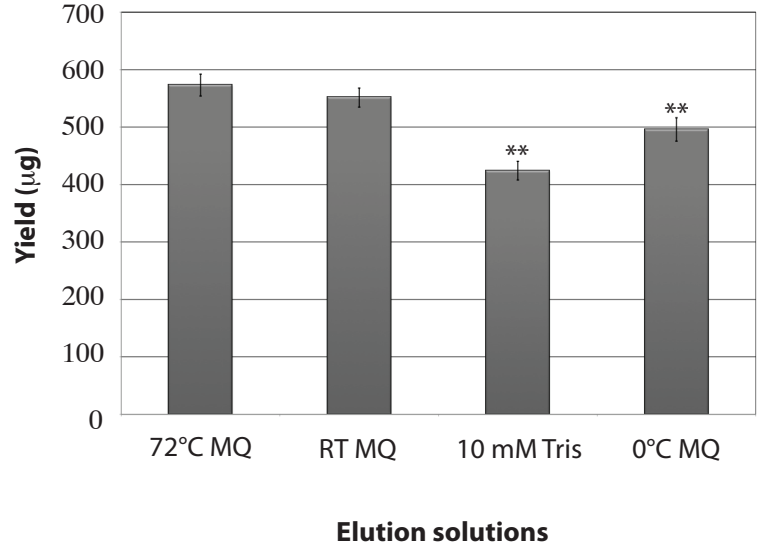

Fig. 2 Hot water is the best solution to elute plasmids from the resin. Isopropanol-precipitated pcDNA3 plasmid from a 50 -ml culture was equally divided into 4 columns for 4 different elution solutions: $72{ }^{\circ} \mathrm{C}$ Milli-Q water, $10 \mathrm{mM}$ Tris$\mathrm{Cl} \mathrm{pH}$ 8.0, room temperature, and ice-chilled Milli-Q water. MQ is abbreviated for Milli-Q. Data bars are the averages ( \pm standard deviation) of three independent experiments. The two asterisks indicate significant difference $(p<0.01)$ from the reference condition $\left(72^{\circ} \mathrm{C} \mathrm{MQ}\right.$ water) based on Student's $t$ test.

produce the same yield for plasmids of different sizes. To our knowledge, the relationship between the size of and the yield of the DNA purified with DE has not been studied. Thus we utilized 4 plasmids: pCI vector (4008 bp), pCI-HAhIRF3 (5308 bp), pcDNA3 vector (5446 bp), and pUC18 (2686 bp). Both pCI (Promega) and pcDNA3 (Invitrogen) vectors contain the same f1 origin of replication ${ }^{4}$, whereas pUC18 contains a mutated ColE1 origin of replication ${ }^{5}$. An origin of replication controls the copies number of the plasmid DNA in bacterial cell. The results showed that both pCI-HAhIRF3 and pcDNA3 plasmids conferred the highest yield, whereas the pUC18 had the lowest yield, suggesting that the yield is proportional to the size of the DNA (Fig. 3). Interestingly, the ratio between the yield $(\mu \mathrm{g})$ and the number of basepairs (kbp) of pCI and pcDNA3 plasmids was comparable, while the ratio of pUC18 plasmid was significantly lower (Fig. 3). Thus these results suggest that DE does not preferentially bind to large size plasmids. Although large size plasmids may have a higher yield, they have the same number of moles with other plasmids that have the same origin of replication. It would be interesting to see if pUC18 with an insert would produce a consistent ratio compared with the vector itself.

Consistently, all plasmids purified were fraction- 


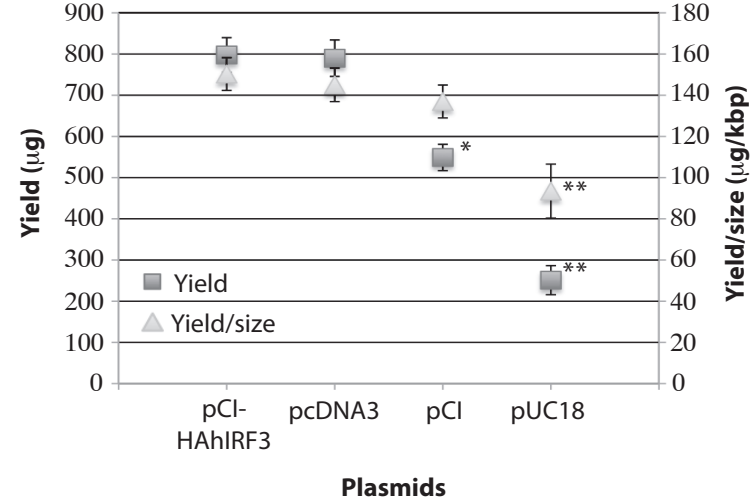

Fig. 3 DE purification of plasmids at different sizes. the yield of the four plasmids: pCI-HAhIRF3 (5308 bp), pcDNA3 (5446 bp), pCI (4008 bp), and pUC18 (2686 bp) were compared. The yield $(\mu \mathrm{g})$ of each plasmid is represented in a rectangular, whereas the ratio between the yield and the size $(\mu \mathrm{g} / \mathrm{kbp})$ is in a triangle. Data presented are the averages ( \pm standard deviation) of three independent experiments. One and two asterisks indicate significant differences $(p<0.05)$ and $(p<0.01)$, respectively, from the reference plasmid (pcDNA3) based on Student's $t$ test.

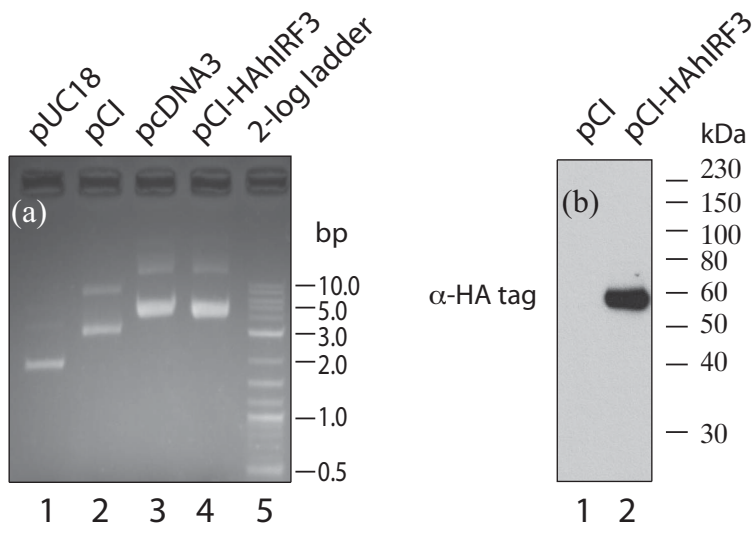

Fig. 4 Analysis of purified plasmids with agarose gel electrophoresis and transfection experiment (a) Ethidium bromide stained agarose gel show four different plasmids purified with this method. Top and bottom bands on each lane represent open circular and supercoiled plasmids, respectively. (b) purified plasmids from this protocol are suitable for transfection experiments. Purified pCI-HAhIRF3 plasmid was transfected into the HEK293T cells, using LT1 (Mirus). Expression of HA-tagged hIRF3 was analysed by Western blotting, using anti-HA tag polyclonal antibodies (ABCAM).

ated into two major species in an agarose gel electrophoresis. A fast migrating band consisting of a supercoiled or covalently closed circular plasmid
Table 1 Absorbances of plasmids purified with this technique.

\begin{tabular}{lccccc}
\hline Construct & $\#$ & Dilution & $\mathrm{A}_{260}$ & $\mathrm{~A}_{280}$ & $\mathrm{~A}_{260} / \mathrm{A}_{280}$ \\
\hline pCI-HAhIRF3 & 1 & 20.00 & 0.617 & 0.323 & 1.912 \\
pCI-HAhIRF3 & 2 & 20.00 & 0.559 & 0.293 & 1.910 \\
pCI-HAhIRF3 & 3 & 20.00 & 0.595 & 0.307 & 1.940 \\
pcDNA3 & 1 & 20.00 & 0.590 & 0.308 & 1.916 \\
pcDNA3 & 2 & 20.00 & 0.558 & 0.293 & 1.905 \\
pcDNA3 & 3 & 20.00 & 0.603 & 0.315 & 1.913 \\
pCI & 1 & 20.00 & 0.441 & 0.220 & 2.004 \\
pCI & 2 & 20.00 & 0.408 & 0.222 & 1.838 \\
pCI & 3 & 20.00 & 0.375 & 0.196 & 1.914 \\
pUC18 & 1 & 20.00 & 0.165 & 0.088 & 1.875 \\
pUC18 & 2 & 20.00 & 0.180 & 0.095 & 1.895 \\
pUC18 & 3 & 20.00 & 0.120 & 0.063 & 1.904 \\
pCI-hTrim21 & 1 & 20.00 & 0.508 & 0.273 & 1.861 \\
pCI-hTrim21 & 2 & 20.00 & 0.645 & 0.342 & 1.886 \\
pCI-hTrim21 & 3 & 20.00 & 0.615 & 0.331 & 1.858 \\
pCI-hTrim21 & 4 & 20.00 & 0.524 & 0.284 & 1.845 \\
pCI-hFaddHisFlag & 1 & 30.00 & 0.316 & 0.174 & 1.816 \\
pCI-hFaddHisFlag & 2 & 30.00 & 0.308 & 0.169 & 1.822 \\
pCI-hFaddHisFlag & 3 & 30.00 & 0.255 & 0.138 & 1.848 \\
pCI-hFaddHisFlag & 4 & 30.00 & 0.312 & 0.165 & 1.891 \\
pCI-HAhTrim39 & 1 & 15.00 & 0.444 & 0.243 & 1.827 \\
\hline
\end{tabular}

\#: Purification number.

(CCC) and a slower band on top represents an open circular form of plasmid can be seen (Fig. 4a). These two bands are normally found in plasmid DNA ${ }^{6}$. All plasmids purified with this protocol have an $\mathrm{A}_{260} / \mathrm{A}_{280}$ ratio within the range of 1.8-2.0 (Table 1) and can be used for transfection (Fig. 4b) or DNA sequencing (data not shown). Together, these data suggest that plasmids purified using this technique are of high quality. One disadvantage of this protocol for the plasmid DNA isolation is that the filtration after adding solution 3 takes almost $1 \mathrm{~h}$. However, we found that the filtration removed many impurities, which may interfere with the subsequent purification with the DE (data not shown). Despite the lengthy purification time, this protocol does not require commercial plastic columns, a vacuum pump, and a vacuum manifold, making this protocol accessible for most laboratories. Since all other plastic wares can be washed and reused many times, the major costs of the plasmid purification results from purchasing $\mathrm{GuHCl}$ (Sigma 50 950, $1 \mathrm{~kg}$ ), diatomaceous earth (Sigma D5509, $1 \mathrm{~kg}$ ), isopropanol (LabScan, 4 1), and absolute ethanol (Macron, 2.5 1). Hence the cost for one plasmid purification was estimated to be 27 baht (7\% Vat included) or less than US\$1, making this plasmid purification protocol relatively inexpensive and affordable. 
Acknowledgements: All plasmids except for pUC18 were gifts from Prof. Dr Astar Winoto at the University of California at Berkeley. CJ receives the Science Achievement Scholarship of Thailand (SAST). This work was financially supported in part by the SAST Research Professional Development Project and the Thai government budget, fiscal year 2011 (SCI540034S).

\section{REFERENCES}

1. Vogelstein B, Gillespie D (1979) Preparative and analytical purification of DNA from agarose. Proc Natl Acad Sci USA 76, 615-9.

2. Iyer R (1993) Resin based DNA purification technology. Methods mailing list, IUBio Archive, Indiana Univ Biology Dept. [Available online at www.bio.net $/ \mathrm{mm} /$ methods/1993-November/009411.html].

3. Machesky L (1996) Plasmid preparations with diatomaceous earth. In: Harwood AJ (ed) Basic DNA and RNA Protocols. Methods in Molecular Biology vol. 58. Humana Press, Totowa, NJ, pp 269-72.

4. Dotto GP, Enea V, Zinder ND (1981) Functional analysis of bacteriophage f1 intergenic region. Virology 114, 463-73.

5. Yanisch-Perron C, Vieira J, Messing J (1985) Improved M13 phage cloning vectors and host strains: nucleotide sequences of the M13mp18 and pUC19 vectors. Gene 33, 103-19.

6. Willshaw GA, Smith HR, Anderson ES (1979) Application of agarose gel electrophoresis to the characterization of plasmid DNA in drug-resistant enterobacteria. J Gen Microbiol 114, 15-25. 